\title{
Total and Free Triiodothyronine in Human Serum*
}

\author{
Janusz A. Nauman, $\ddagger$ Alicja Nauman, $\S$ and Sidney C. Werner $\|$ \\ (From the Department of Medicine, Columbia University College of Physicians \& Surgeons \\ and The Presbyterian Hospital in the City of New York)
}

\begin{abstract}
Summary. A reliable method has been developed for the determination of total serum T3, dialyzable fraction (DFT3), and absolute concentration of free T3 (AFT3). Total T3 values (mean \pm sD) were: healthy euthyroid subjects, $0.33 \pm 0.07 \mu \mathrm{g}$ per $100 \mathrm{ml}$; hyperthyroid patients, $0.71 \pm 0.1 \mu \mathrm{g}$ per 100 $\mathrm{ml}$; hypothyroid, $0.10 \pm 0.03 \mu \mathrm{g}$ per $100 \mathrm{ml}$. Values (mean $\pm \mathrm{sD}$ ) for DFT3 in these groups were $0.46 \pm 0.14 \%, 0.78 \pm 0.17 \%$, and $0.16 \pm 0.08 \%$, respectively. Calculated values for AFT3 were: $1.51 \pm 0.4 \mathrm{~m} \mu \mathrm{g}$ per $100 \mathrm{ml}, 5.00 \pm$ $0.6 \mathrm{~m} \mu \mathrm{g}$ per $100 \mathrm{ml}$ and $0.24 \pm 0.1 \mathrm{~m} \mu \mathrm{g}$ per $100 \mathrm{ml}$, respectively. Dilution of serum before dialysis lowered estimated DFT3 values. Enrichment of serum with labeled T3 in the range examined did not affect DFT3. However, DFT3 was increased by addition of Merthiolate to serum in concentration 1:10,000 due to displacement of $\mathrm{T} 3$ from thyroxine-binding globulin to albumin. The data suggest that triiodothyronine may play a considerably more important role in normal and pathological physiology, as evidenced by kinetic analysis using these data. A metabolic role for T3 equal to that of T4 is indicated.
\end{abstract}

\section{Introduction}

The present report describes a method which permits quantitation by weight of total and of dialyzable triiodothyronine. Preliminary results are presented from euthyroid subjects and from hyperand hypothyroid patients. Some of the factors which influence the determination have been analyzed.

Triiodothyronine was discovered in 1952 and was suggested as a second thyroid hormone $(1,2)$. Knowledge however is still limited about the concentrations that exist in human serum. In a few reports (3-6), triiodothyronine (T3) was esti-

\footnotetext{
* Submitted for publication March 3, 1967; accepted May 18, 1967.

This study was aided by grant AM 00008 ( $\mathrm{C} 17$ and 18), National Institutes of Health, U. S. Public Health Service.

¥International postdoctoral research fellow (2-F05TW-843-01), U. S. Public Health Service. Permanent address: II Department of Medicine, Postgraduate Medical School, Warsaw, Poland.

$\S$ Permanent address : II Department of Medicine, Postgraduate Medical School, Warsaw, Poland.

II Address all reprint requests to Dr. Sidney C. Werner, Department of Medicine, 630 West 168th Street, New York, N. Y. 10032.
}

mated by means of a radiochemical method and the results expressed as a percentage of total protein-bound iodine in serum. The concentration of hormone was also determined by a chemical method $(7,8)$. Unfortunately, the catalytic activity of T3 in the Sandell-Kolthoff reaction is weak (9), and the low concentrations present in normal plasma make the accuracy of these determinations doubtful.

Recent workers (10-12) have postulated that only the unbound portion of the thyroid hormones is physiologically active. Thus, the difficulty which exists in determining total $\mathrm{T} 3$ becomes a limiting factor in estimating absolute concentrations of the free hormone. To date, only the percentage of total $\mathrm{T} 3$ considered to be free has been measured, by means of dialysis $(12,13)$ or dextran gel filtration (14).

\section{Methods}

L-Triiodothyronine- ${ }^{125} \mathrm{I}$ ( T3 ${ }^{125} \mathrm{I}$ ) and L-triiodothyronine${ }^{131} \mathrm{I}$ ( T3 ${ }^{131} \mathrm{I}$ ) in propylene glycol solution were obtained from Abbott Laboratories ${ }^{1}$ with specific activity of at least $30 \mathrm{mc}$ per $\mathrm{mg}$. All preparations, as well as the stable compounds used as standards, were tested for purity

\footnotetext{
1 Abbott Laboratories, North Chicago, Ill.
} 
either by paper chromatography (descending phase), or by thin-layer chromatography (TLC) (ascending phase), as described below. Samples containing other iodo-compounds besides T3 were purified further by chromatography until a single spot, T3, was present on TLC. T3 thus isolated was eluted and dissolved in $0.125 \%$ solution of human albumin to a concentration of $0.5 \mu \mathrm{g}$ of labeled T3 per $10 \mathrm{ml}$.

In addition to the labeled materials, the following stable chemicals were used: thyroxine (T4), triiodothyronine (T3), diiodotyrosine, monoiodotyrosine ${ }^{2}$; tertiary butanol ${ }^{3}$; tertiary amyl alcohol ${ }^{3}$; acetone ${ }^{3}$ (spectroanalyzed) ; chloroform ${ }^{3}$; sulfuric acid ${ }^{3}$; sodium hydroxide ${ }^{3}$; bromothymol blue ${ }^{3}$; ammonium hydroxide ${ }^{3}$; magnesium chloride ${ }^{3}$; mono- and dibasic potassium phosphate ${ }^{3}$; Merthiolate powder ${ }^{4}$; Tris maleate buffer $\mathrm{pH} 8.6^{5}$; Veronal buffer $\mathrm{pH} 8.6^{6}$

TLC silica gel plates, type $\mathrm{K}$ 301-R2, were obtained from a commercial source, ${ }^{7}$ as were Visking cellulose casing ${ }^{8}$ and Sephadex G-25 and Sephadex LH-20.9

Healthy subjects and patients in the Thyroid Clinic or admitted to the hospital were studied. The patients had either hyperthyroidism or hypothyroidism, or were euthyroid on replacement therapy subsequent to total thyroidectomy. Diagnoses were verified both by clinical examination and by routine laboratory tests. Blood was obtained and centrifuged within an hour or two. Sera thus obtained were either processed immediately or were deep frozen for later use.

Extraction of serum. 10-ml samples of serum were used, to which T3 ${ }^{125} \mathrm{I}, 0.001-0.002 \mu \mathrm{g}$, was added as a recovery standard. The mixture was placed in a $500 \mathrm{ml}$ separatory funnel, $200 \mathrm{ml}$ of a freshly prepared mixture of methanol:chloroform $(1: 1 \mathrm{v} / \mathrm{v})$ was added, and the contents were shaken for $3 \mathrm{~min}$. Then $50 \mathrm{ml} 0.03 \mathrm{~N}$ sulfuric acid was introduced and the whole mixed by further shaking for $5 \mathrm{~min}$. Equilibration of the water-solvent system was permitted for $10 \mathrm{~min}$. Three distinct phases separated out: (a) a chloroform phase containing most of the serum lipids at the bottom; $(b)$ a precipitated protein phase in the middle; and $(c)$ an acidified methanolwater phase at the top, containing most of the iodocompound content.

The bottom phase was removed and saved. The remaining two phases were mixed together and filtered through a Buchner funnel (Whatman paper No. 1) into a round bottom flask. The chloroform phase was then reintroduced into the separatory funnel and washed with $100 \mathrm{ml}$ of methanol: $\mathrm{H}_{2} \mathrm{O}(1: 1 \mathrm{v} / \mathrm{v})$ by thorough mixing. Separations were seemingly complete after $10 \mathrm{~min}$. The

2 Mann Research Laboratories, New York, N. Y.

${ }^{3}$ Fisher Scientific Company, New York, N. Y.

4 Eli Lilly \& Co., Indianapolis, Ind.

5 Sigma Chemical Co., St. Louis, Mo.

${ }^{6}$ Spinco Division, Beckman Instruments, Inc., Palo Alto, Calif.

7 Distillation Products Industries, Rochester, N. Y.

8 Union Carbide Corp., Visking Division, Chicago, Ill.

${ }^{9}$ Pharmacia, Upsala, Sweden. methanol-water phase was filtered as above and added to the original acidified methanol-water extract in the round bottom flask.

The total extract was adjusted to $\mathrm{pH} 7.0 \pm 0.2$ with $0.1 \mathrm{~N}$ sodium hydroxide and evaporated in vacuo to dryness. The dry residue was dissolved in $5 \mathrm{ml}$ of deionized water and adjusted to $\mathrm{pH} 5.5-6.0$ with $0.01 \mathrm{~N}$ hydrochloric acid. 1 drop of $0.2 \%$ bromothymol blue was introduced as an indicator. The redissolved acidic extract was quantitatively transferred to a column packed with Sephadex LH-20.

Preparation of gel and column. Dry Sephadex LH-20 was carefully prepared for column chromatography by usual procedure. A glass column $10 \mathrm{~mm}$ i.d. $\times 200 \mathrm{~mm}$ was fitted with a plug of glass wool and Teflon stopcock. The column was filled with deionized water and sufficient slurry was poured in to obtain a gel column 4 $\mathrm{cm}$ high. The settled gel was kept wet by a continuous flow of water. Before the sample was added to the prepared column, water flow was stopped and residual water was removed except for approximately $0.1 \mathrm{ml}$. The stopcock was closed and serum extract $(5 \mathrm{ml})$ was pipetted onto the top of the column. The stopcock was then partially opened and the sample allowed to penetrate the gel. The walls of the column were washed down twice with $2 \mathrm{ml}$ of distilled water each time. An aqueous fraction was then eluted with $35 \mathrm{ml}$ of distilled water. With the stopcock wide open, a flow rate of $6-8$ drops per minute was established. This step permitted salts to be eluted and removed with the water.

Thyroid hormones were then eluted with $10 \mathrm{ml}$ of methanol:ammonia $(90: 10 \mathrm{v} / \mathrm{v})$. During elution with the organic solvent, air bubbles occasionally formed. This phenomenon, however, did not influence the efficiency of elution. The eluate was collected in $15-\mathrm{ml}$ centrifuge plastic tubes and evaporated to dryness under air at $37^{\circ} \mathrm{C}$.

Chromatographic separation of iodoamino acids. The extract from the methanol-ammonia eluate was dried and quantitatively transferred to either silica gel plates (activated before use at $100^{\circ} \mathrm{C}$ for $20 \mathrm{~min}$ ) or Whatman No. 3 paper, with methanol: ammonia (99:1 v/v). If TLC was used, the sample was divided in three and each third applied to a separate spot. This permitted better separation. Paper chromatography was conducted by descending technique in a tertiary amyl alcohol:ammonia solvent system (15). TLC was performed with a tertiary amyl alcohol: tertiary butanol:6 $\mathrm{N}$ ammonia: acetone solvent system $(10: 10: 20: 80 \mathrm{v} / \mathrm{v})$, and ascending technique, to a solvent front $16-17 \mathrm{~cm}$ above the origin. This required about $2 \mathrm{hr}$ or less. After chromatography was completed, the TLC plates or paper were dried at room temperature. The position of $\mathrm{T} 3$ on the chromatograms was determined both by radioautography 10 and by comparison with the position of standards applied to the same plate or paper and developed with arsenious acidceric sulfate system as described elsewhere (15). T3

10 Ansco high speed X-ray films were used for radioautography. 
spots were cut out and eluted with methanol:ammonia $(99: 1 \mathrm{v} / \mathrm{v})$ by descending flow technique in a Gelman chromatocab. ${ }^{11}$ Approximately $5 \mathrm{ml}$ of the eluate was collected in $15-\mathrm{ml}$ plastic centrifuge tubes and evaporated to dryness under air at $37^{\circ} \mathrm{C}$.

Quantitation of total T3. The known competition for T4 which takes place between serum thyroxine-binding globulin (TBG) and added dextran gel (16) has been used as the basis for determining the amount of $\mathrm{T} 4$ in serum (16). The Murphy-Pattee procedure for $\mathrm{T} 4$ had to be slightly modified in order to be usable for T3 measurement. Dry Sephadex G-25, $250 \mathrm{mg}$, was allowed to swell in distilled water and was then packed in a column. The column-packing procedure was the same as that described above for Sephadex LH-20. Before use, the column was equilibrated with $20 \mathrm{ml}$ Veronal buffer, $\mathrm{pH} 8.6$, ionic strength 0.075 . "Isotope solution" (16) of T3 ${ }^{131} \mathrm{I}$ was prepared as follows. $0.2 \mu \mathrm{g}$ of previously purified T3 ${ }^{131} \mathrm{I}, 6 \mathrm{ml}$ of pooled serum, and $2 \mathrm{ml}$ of propylene glycol were mixed and the whole sample was di-

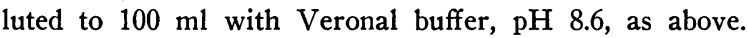
Working solutions of stable T3 which contained the hormone in concentrations of from 0.0025 to $0.060 \mu \mathrm{g}$ per 1 $\mathrm{ml}$ of methanol:ammonia $(99: 1 \mathrm{v} / \mathrm{v})$ were used to prepare a standard curve after correction for water of crystallization. The weight of standard T3 dissolved was that amount wanted $\times 1.089$.

$1 \mathrm{ml}$ of isotope solution containing $\mathrm{T} 3{ }^{131} \mathrm{I}$ was added to the dry eluate from TLC or paper obtained above and the mixture incubated at $37^{\circ} \mathrm{C}$ for $30 \mathrm{~min}$. After incubation, the sample was allowed to cool to room temperature and radioactivity was assayed in a Packard Autogamma welltype scintillation counter. The contents of the tube were then transferred quantitatively with Veronal buffer to a Sephadex G-25 column. The protein-bound fraction was eluted as previously described (16). A $1 \mathrm{ml}$ aliquot of this $5 \mathrm{ml}$ eluate containing the labeled $\mathrm{T} 3$ bound to the serum proteins was assayed for radioactivity in a Packard Autogamma counter. Total counts per minute in the eluate were determined by multiplying the result from the $1 \mathrm{ml}$ aliquot by 5 . Percentage bound $\mathrm{T} 3$ was calculated by dividing net counts per minute in the protein-bound fraction by total net counts per minute of $\mathrm{T} 3$ ${ }^{131} \mathrm{I}$, determined by counting each sample before incuba-

11 Gelman Instrument Company, Ann Arbor, Mich. tion. Counts from the amount of $\mathrm{T} 3{ }^{125} \mathrm{I}$ used as a recovery standard were relatively negligible and were not taken into account. The standard curve was obtained as in the method for T4 determination (16) and the values of per cent bound $\mathrm{T} 3{ }^{131} \mathrm{I}$ were plotted on semilogarithmic paper against added micrograms of unlabeled $\mathrm{T} 3$. To express total $\mathrm{T} 3$ as $\mu \mathrm{g}$ of $\mathrm{T} 3$ (not $\mathrm{T} 3$ iodine) per 100 $\mathrm{ml}$ of serum, the values obtained from the standard curve were multiplied by $10 \times 100 / R$ where $R$ is the final recovery of $\mathrm{T} 3{ }^{125} \mathrm{I}$ in per cent. All determinations of $\mathrm{T} 3$ in unknown sera were made in duplicate; the standard curve was prepared from readings made in triplicate. Each measurement of radioactivity was repeated at least three times, and the mean value used. Counting accuracy was within $1-2 \%$.

Determination of dialyzable serum T3. The method of Sterling and Brenner (17) for determination of dialyzable T4, which consists of equilibrium dialysis and subsequent magnesium precipitation of the dialysate, was employed as a basis for determination of the dialyzable fraction of T3 (DFT3). Several modifications were necessary. Acid washing and soaking of the dialysis tubing were omitted. All tubing was washed in distilled water and soaked in potassium phosphate buffer $\mathrm{pH} 8.6$ for $4 \mathrm{hr}$ before use. We found a 1:20,000 solution of Merthiolate in phosphate buffer was optimal in preventing bacterial growth during equilibrium dialysis, rather than the 1: 10,000 dilution used in the T4 method.

Purified T3 ${ }^{125} \mathrm{I}$ or T3 ${ }^{131} \mathrm{I}$ obtained in human albumin solution as described above was added to $5 \mathrm{ml}$ of serum (maximum $0.1 \mu \mathrm{g}$ of labeled T3 per $100 \mathrm{ml}$ ). After incubation for $15 \mathrm{~min}$, the serum was placed inside the prepared dialysis tubing and dialysis performed in a $50 \mathrm{ml}$ plastic centrifuge tube for $18 \mathrm{hr}$ at $37^{\circ} \mathrm{C}$ against an equal volume of potassium phosphate buffer, $\mathrm{pH} 7.4$, ionic strength 0.15 . At the end of dialysis, equal volumes of dialysate and, to keep comparable counting conditions, of serum from the cellulose bag were precipitated by $40 \%$ magnesium chloride solution, $\mathrm{pH} 9.2$, and then washed by $40 \%$ magnesium chloride solution, $\mathrm{pH} 8.8$. $1 \mathrm{ml}$ of stable T3 solution ( $1 \mathrm{mg}$ per $100 \mathrm{ml}$ of solution) was added for better precipitation. The final precipitates were counted in a Nuclear-Chicago scintillation counter. The DFT3 was calculated as follows:

$$
\text { DFT3 }=\frac{c p m \text { in dialysate }}{\mathrm{cpm} \text { in serum }+ \text { cpm in dialysate }} .
$$

TABLE I

$R_{f}$ values of standard iodoamino acids subjected to paper and thin-layer chromatography

\begin{tabular}{|c|c|c|c|c|}
\hline \multirow[b]{2}{*}{ Compound } & \multicolumn{2}{|c|}{ Paper chromatography } & \multicolumn{2}{|c|}{ Thin-layer chromatography } \\
\hline & Average & Range & Average & Range \\
\hline Diiodotyrosine & 0.021 & $0.018-0.024$ & 0.108 & $0.103-0.114$ \\
\hline Monoiodotyrosine & 0.090 & $0.081-0.100$ & 0.181 & $0.174-0.188$ \\
\hline Sodium iodide & 0.240 & $0.220-0.250$ & 0.688 & $0.663-0.719$ \\
\hline Thyroxine & 0.560 & $0.521-0.620$ & 0.407 & $0.380-0.434$ \\
\hline Triiodothyronine & 0.735 & $0.710-0.750$ & 0.522 & $0.490-0.554$ \\
\hline Triiodothyronine in serum extracts & 0.740 & $0.720-0.750$ & 0.545 & $0.495-0.583$ \\
\hline
\end{tabular}

See text for solvents used. 
To express the absolute concentration of free $\mathrm{T} 3$ (AFT3) in $\mathrm{m} \mu \mathrm{g}$ per $100 \mathrm{ml}$ of serum, the DFT3 value was multiplied by the total $\mathrm{T} 3$ value determined as above.

\section{Results}

Methodological variables. Recovery of standard $\mathrm{T} 3{ }^{125} \mathrm{I}$ was determined at the various major

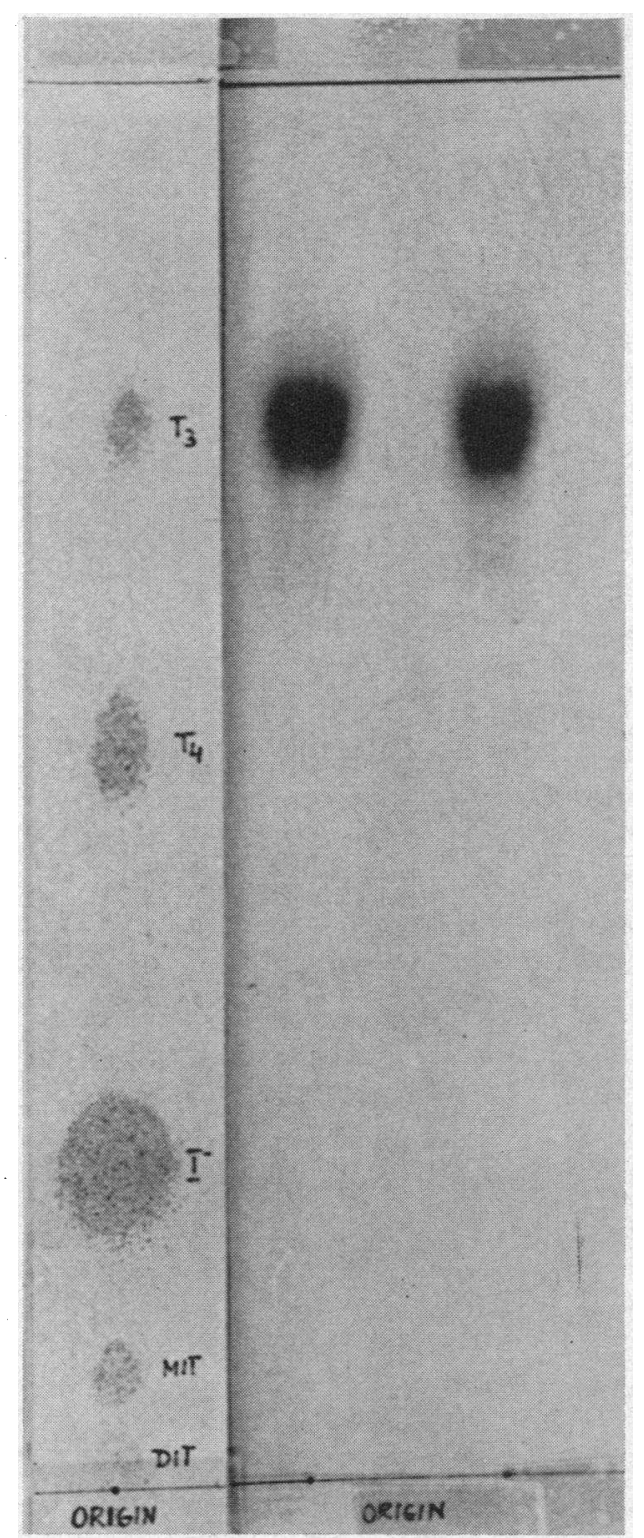

Fig. 1. Chromatographic SEParations of Standard AND SERUM IODOAMINO ACIDS ON PAPER: POSITION OF T3 EXTRACTED FROM SERUM MARKED BY RADIOAUTOGRAPHIC TECHNIQUE. Standard compounds are shown on the left, and were developed and sprayed by As-Ce technique.

$T 3$, triiodothyronine; $T 4$, thyroxine; $M I T$, monoiodotyrosine; $D I T$, diiodotyrosine. steps of the extraction procedure. In 64 experiments, mean $\pm \mathrm{SD}$ recovery after lipid removal averaged $88.6 \pm 3.8 \%$. After use of a Sephadex LH-20 column for the purpose of desalting, little T3 was lost, mean $3.1 \pm 1.3 \%$. The final serum extract was clear and thus permitted good separa-

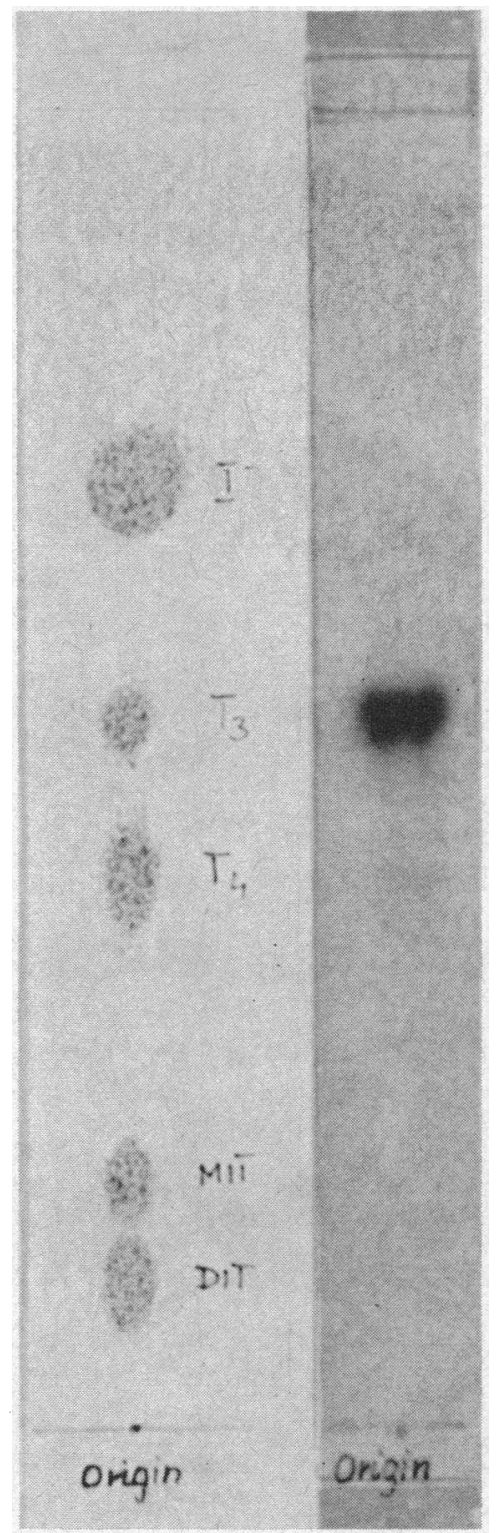

Fig. 2. Chromatographic separation (TLC) of STANDARD IODOAMINO ACIDS AND T3 FROM SERUM: POSITION OF T3 EXTRACTED FROM SERUM MARKED BY RADIOAUTOGRAPHIC TECHNIQUE. Standard compounds are shown on the left and were developed as in Fig. 1.

Abbreviations as in legend to Fig. 1. 


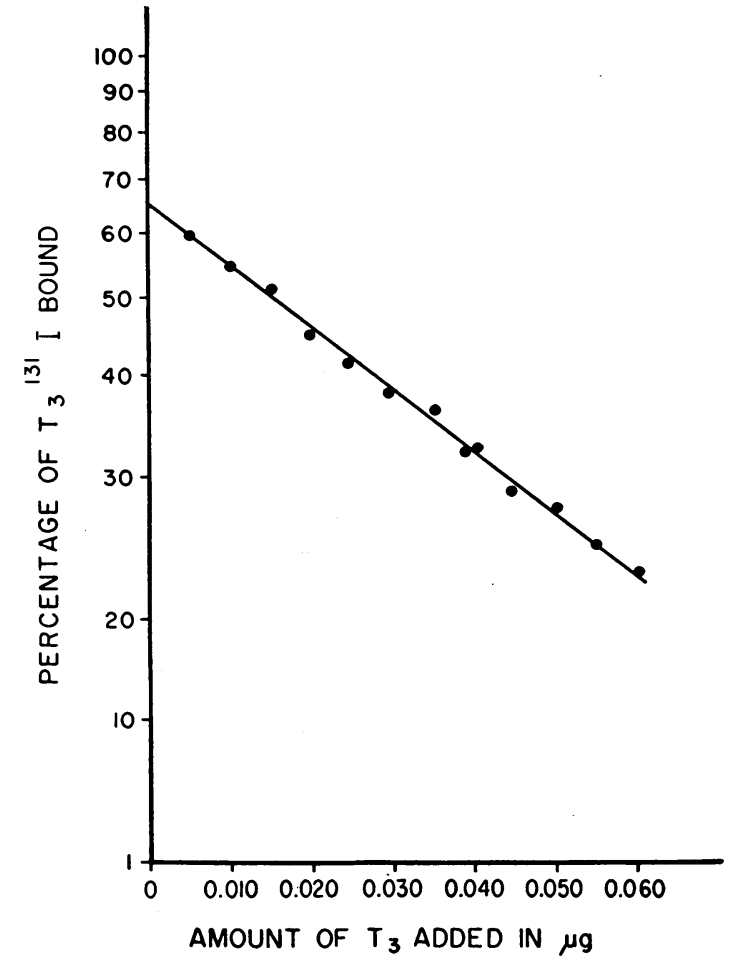

Fig. 3. Curve (SERUM dilution $1: 16$ ) Showing the RELATIONSHIP BETWEEN PERCENTAGE BOUND T3 ${ }^{131} \mathrm{I}$ AND AMOUNTS OF STANDARD T3 ADDED TO A NORMAL SERUM POOL (SEMILOG PLOT).

tion of iodoamino acids on paper and silica gel plates.

$R_{f}$ values in our systems for iodocompounds are shown in Table I. The locations on the chromatograms of stained standard T3 and of labeled T3 from serum extracts coincided exactly, as revealed by radioautography (Figures 1 and 2). Elution of T3 was accomplished as stated above by descending flow, whether from paper or silica gel plate. This step was fast and efficient, and permitted the hormone to be obtained in a small volume of methanol. Losses from chromatographic separation and elution averaged only $8.4 \pm 1.2 \%$. Thus, final recovery of $\mathrm{T} 3$ for the entire procedure was $67.4 \pm 8.1 \%$.

The standard curve constructed for the quantitative determination of $\mathrm{T} 3$ in the last step of the method (Figure 3) was found to be suitable for low, medium, or high T3 concentrations, when 10-ml samples of serum were extracted. As in the method for determination of T4 (16), the rise and slope of the standard curve varied with changes in amount of serum employed to make up the solution containing labeled standard T3, and in amount of Sephadex G-25 used to pack the column. Optimum results were obtained with $6 \mathrm{ml}$ of serum diluted $1: 16$, and $250 \mathrm{mg}$ of Sephadex per column. As with $\mathrm{T} 4$, increases in temperature raised the amount of T3 bound to Sephadex.

The addition of as little as $0.001 \mu \mathrm{g}$ of $\mathrm{T} 4$ to the final extract produced a significant increase (roughly $0.01 \mu \mathrm{g}$ of $\mathrm{T} 3$ per $100 \mathrm{ml}$ ) in the value determined for total T3. Thus, T4 contamination during the procedure was insured against by completely adequate separation of the iodocompounds on the chromatograms. As stated above, the reliability of the chromatographic separation was checked repeatedly, by rechromatography of the eluted T3 material from the original paper or silica gel plate chromatograms; only a single $\mathrm{T} 3$ spot

TABLE II

Separation of labeled standard T4 and labeled standard T3 by the thin-layer chromatographic procedure described in the text*

\begin{tabular}{|c|c|c|c|c|c|c|}
\hline & & \multicolumn{5}{|c|}{ Recovered } \\
\hline \multicolumn{2}{|c|}{ Added labeled compound } & \multicolumn{2}{|c|}{ 125I compound } & & \multicolumn{2}{|c|}{131 I compound } \\
\hline$\underset{125 I}{T 4}$ & $\begin{array}{r}\mathrm{T} 3 \\
131\end{array}$ & T4 & T3 & & $\mathrm{T4}$ & T3 \\
\hline & & & & $c p m$ & & \\
\hline 0.1 & 0 & 125,564 & $\begin{array}{c}5022 \\
(3.9 \%) \ddagger\end{array}$ & & 一 & 一 \\
\hline 0 & 0.01 & 一 & 一 & & - & 47,236 \\
\hline 0.1 & 0.01 & 114,238 & $\begin{array}{c}4569 \\
(4.0 \%) \ddagger\end{array}$ & & 一 & 45,011 \\
\hline
\end{tabular}

${ }^{*}$ Labeled ${ }^{125} \mathrm{I} \mathrm{T} 4$ contained approximately $4 \%{ }^{125 \mathrm{I}} \mathrm{T} 3$.

$\ddagger$ Per cent of T4 + T3 cpm. 
TABLE III

Recovery of standard T3 added to pooled normal human serum (mean $\pm S D$ )

\begin{tabular}{ccccc}
\hline \multirow{2}{*}{$\begin{array}{c}\text { No. of } \\
\text { experiments }\end{array}$} & Stable T3 added & Determined & Mean stable T3 & SD \\
\cline { 3 - 5 } & $\mu g / 100 m l$ & & $\mu g / 100 \mathrm{ml}$ & -0.04 \\
10 & - & 0.31 & $0.44 ; 0.40$ & 0.41 \\
2 & 0.1 & $0.47 ; 0.53$ & 0.51 \\
2 & 0.2 & $0.67 ; 0.72$ & 0.71 \\
\hline
\end{tabular}

was found. Also, no significant trailing of the appropriate labeled compounds into the neighboring T3 or T4 areas was found (see Table II) and two values for serum $\mathrm{T} 3$ from a thyroidectomized patient on T4 replacement therapy were negligible (see Results).

Serum determinations. The reproducibility and precision of the over-all method for the determination of T3 in serum was checked in two ways. First, 10 determinations were made on aliquots of a single pool of human serum; second, determinations were made in duplicate with aliquots from the same serum pool enriched by the addition of stable $\mathrm{T} 3$ to provide concentrations of $0.01,0.02$, and $0.04 \mu \mathrm{g}$ per $10 \mathrm{ml}$ of serum. As shown in Table III, reproductibility of the determinations was good at each of the four concentrations employed.

The reliability of the procedure for determining the dialyzable T3 fraction (DFT3) was also evaluated. Studies were made of the characteristics of the system during equilibrium dialysis; of the effect of added Merthiolate as a preservative; and of the effect of dilution of the test serum. The results are depicted in Figure 4. Between 16 and $36 \mathrm{hr}$ of dialysis, DFT3 was almost constant, suggesting that equilibrium was achieved by 16 to $20 \mathrm{hr}$.

The effect of Merthiolate was tested in the $1: 10,000$ concentration used for dialyzable $\mathrm{T} 4 \mathrm{de}-$ termination (17) and in a $1: 20,000$ concentration. The former altered the results from those obtained

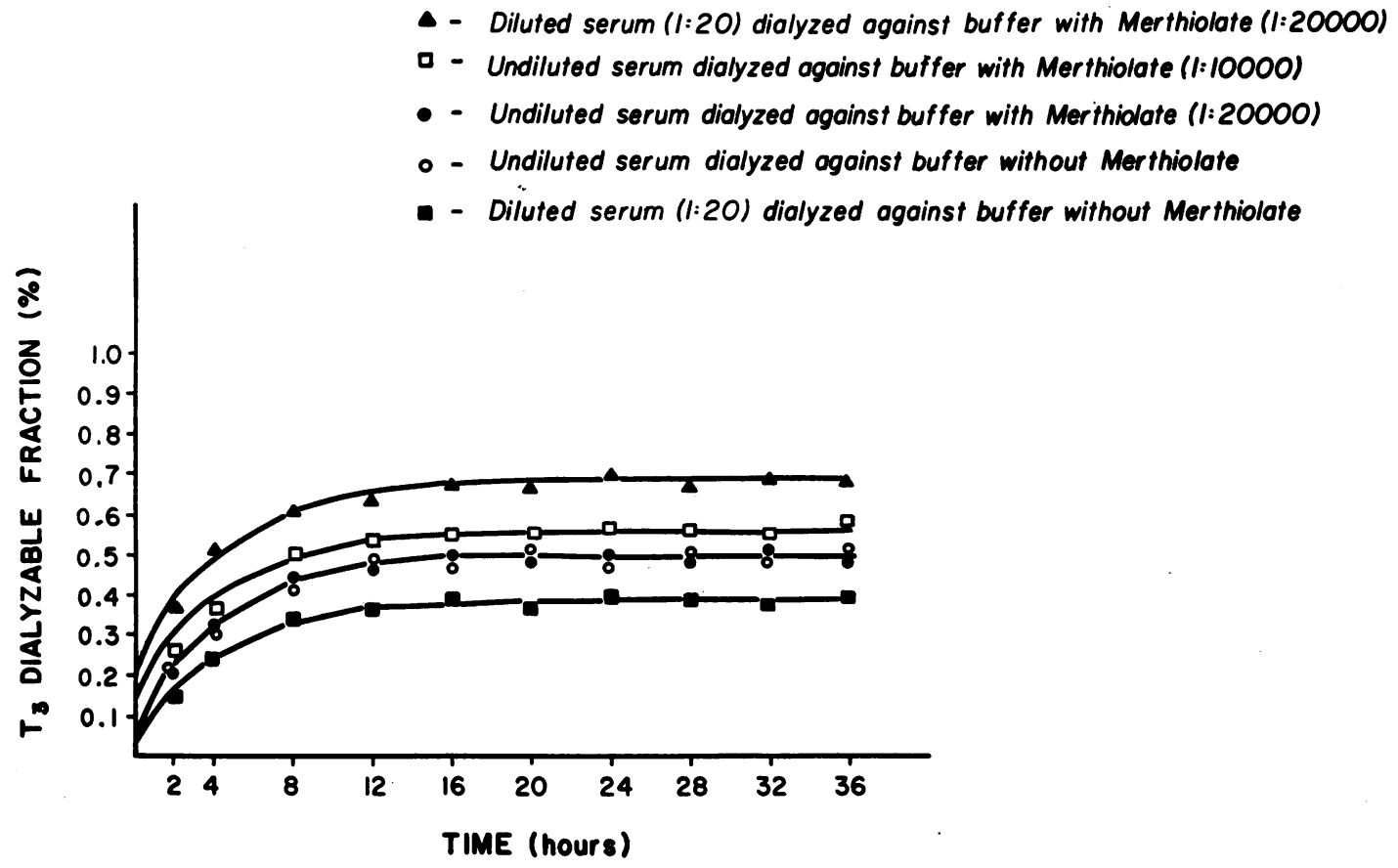

Fig. 4. VAlues fOR DIALYZable FRACTION OF T3 AT VARIOUS EQUILIBRATION TIMES : DILUTED AND UNDILUTED SERUM

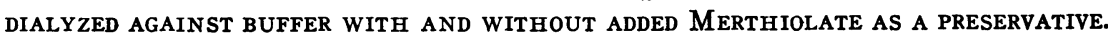


TABLE IV

Effect upon dialyzable T3 fraction of increasing amounts of standard $T 3$ added to pooled serum

\begin{tabular}{cc}
\hline \hline Added T3 & $\begin{array}{c}\text { Determined dialyzable } \\
\text { fraction }\end{array}$ \\
\hline$\mu g / 100 \mathrm{ml}$ & $\%$ \\
0.3 & 0.48 \\
0.6 & 0.47 \\
1.2 & 0.48 \\
2.0 & 0.52 \\
\hline
\end{tabular}

with buffer alone. However, no change from those with buffer alone was observed with the $1: 20,000$ concentration. The $1: 20,000$ dilution of Merthiolate was therefore employed in all subsequent experiments.

The effect of dilution of test serum was examined in a dilution range from $1: 5$ to $1: 150$ with phosphate buffer as the diluent. DFT3 values obtained were compared with those from undiluted serum. Final calculations followed those used for dialyzable T4 determination by Oppenheimer (18). With diluted serum without Merthiolate, DFT3 for any time period of dialysis was always less than that with undiluted serum. However, further dilution of the serum after initial dilution did not further decrease the value. Merthiolate in a concentration 1:20,000 significantly increased DFT3 values for diluted serum as opposed to the lack of effect with undiluted serum (Figure 4).

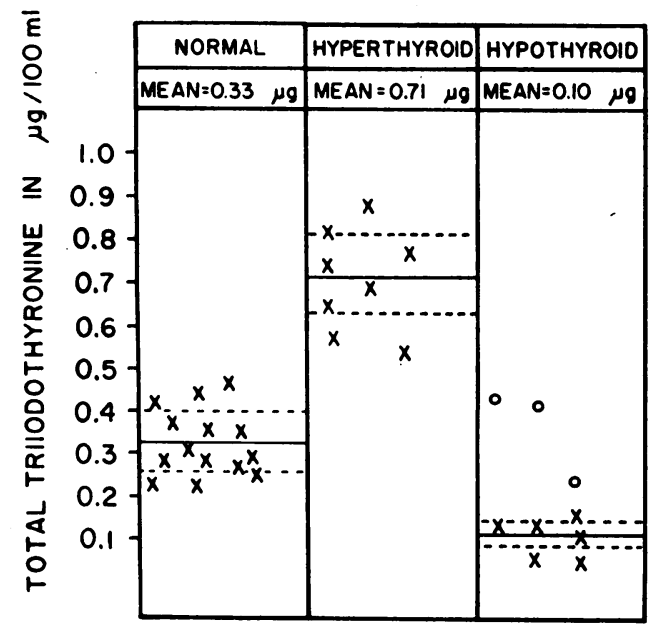

Enrichment of serum with labeled T3 had little effect on DFT3 values. Five experiments were conducted for each concentration employed and the results expressed as an average (Table IV). The addition of as much as $0.1 \mu \mathrm{g}$ of stable T3 (as labeled T3) per $100 \mathrm{ml}$ of serum had no detectable effect upon the final results.

Clinical values. Results from the determinations of total and free $\mathrm{T} 3$ in sera of healthy euthyroid subjects and of patients with hyper- and hypothyroidism are presented in Figure 5. Normal values for total T3 varied from 0.22 to $0.46 \mu \mathrm{g}$ per 100 $\mathrm{ml}$ of serum, mean $0.33 \pm 0.07 \mu \mathrm{g}$ per $100 \mathrm{ml}$. The mean for hyperthyroid patients was more than twice the normal, and, for hypothyroid patients, less than half the normal. Three totally thyroidectomized patients kept euthyroid by substitution therapy with $\mathrm{T} 3$ showed normal total $\mathrm{T} 3$ concentrations and not low ones.

One thyroidectomized patient maintained euthyroid on T4 $0.3 \mathrm{mg}$ daily, had T3 values 2 months apart of 0.011 and $0.013 \mu \mathrm{g}$ per $100 \mathrm{ml}$. Another thyroidectomized patient on T3 $0.05 \mathrm{mg}$ daily had a serum T3 value of $0.22 \mu \mathrm{g}$ per $100 \mathrm{ml}$; but on a mixture of T4 $0.05 \mathrm{mg}$ and T3 $0.0125 \mathrm{mg}$ daily, $0.1 \mu \mathrm{g}$ per $100 \mathrm{ml}$. A last patient of this nature receiving T3 $0.025 \mathrm{mg}$ daily had T3 levels of 0.30 and $0.34 \mu \mathrm{g}$ per $100 \mathrm{ml}, 2$ months apart.

Absolute concentrations of free T3 (AFT3). AFT3 in hyper- and hypothyroidism showed more

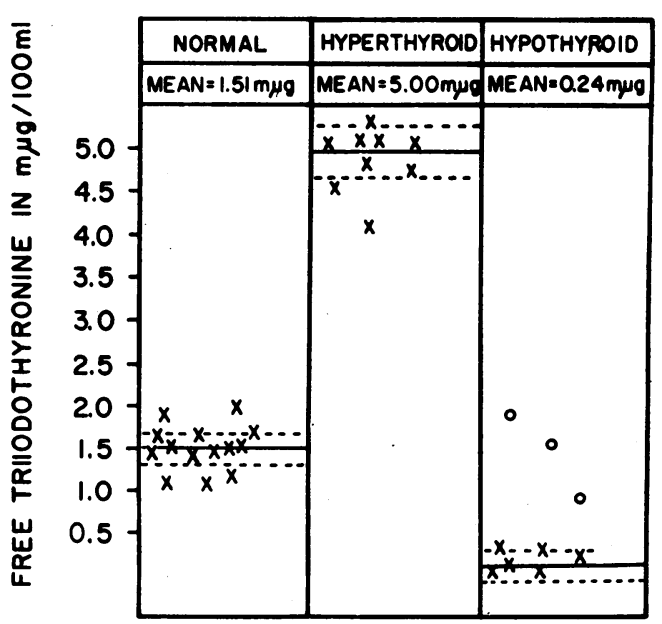

Fig. 5. VAlUes FOR tOTAL T3 AND ABSOlUte CONCENTRATION OF FREE TRIIODOTHYRONINE IN HEALTHY EUTHYROID SUBJECTS OR UNTREATED PATIENTS. Open circles represent values for hypothyroid patients made euthyroid by replacement therapy with T3. Mean values are indicated by horizontal solid lines and standard deviation by broken lines. 
pronounced differences from normal than did total T3. In the normal group, a mean $\pm \mathrm{SD}$ value was determined for AFT3 of $1.51 \pm 0.4 \mathrm{~m} \mu \mathrm{g}$ per $100 \mathrm{ml}$ of serum. In the hyperthyroid patients, the mean AFT3 value was slightly more than three times greater than normal, but in the hypothyroid patients, was approximately only a fifth of normal. The mean $\pm \mathrm{SD}$ DFT3 for the normal subjects was $0.46 \pm 0.14 \%$; for the hyperthyroid group, $0.78 \pm 0.17 \%$; and for the hypothyroid group, $0.16 \pm 0.08 \%$.

\section{Discussion}

A major obstacle to the establishment of a reliable method for determination of total and dialyzable T3 in human serum has been the low concentrations which are present. We therefore used 10 $\mathrm{ml}$ of serum. Such a volume introduces technical problems, for the large amounts of both serum lipids and salts recovered with extraction interfere seriously with chromatographic separation of the iodocompounds, especially on TLC (19). However, an efficient and simple extraction procedure was developed which has permitted virtually complete removal of such interfering compounds.

Also, to help increase the accuracy of the determination, we added $\mathrm{T} 3{ }^{125} \mathrm{I}$ to the serum before extraction. Final recovery for each sample could thus be calculated and radioautography could be used to mark precisely the T3 position. Although the weight of $T 3{ }^{127} \mathrm{I}$ introduced with the label was very low, the value was subtracted from the final serum result.

A modified (8) Sandell-Kolthoff method, and Barker's distillation procedure (20) were employed early in the study to determine amounts of T3 and other iodocompounds in eluates from the chromatograms. The results obtained for $\mathrm{T} 3$ were not reproducible despite the low "binding protein" affinity of T3 (10) compared to that of T4.

However, by the use of the Murphy-Pattee procedure for T4 determination (16), with the modifications above, a high degree of accuracy was obtained. Control of three important variables must be achieved. This can be insured by: $(a)$ use of a $1: 16$ dilution of serum only, in the "isotopic solution"; $(b)$ adequacy of chromatographic separaration of $\mathrm{T} 3$ from $\mathrm{T} 4$; and $(c)$ constancy of the amount of Sephadex used for the competitive binding step.

Several factors which have been found to interfere with determination of the dialyzable fraction of $\mathrm{T} 4$ interfere equally with the determination of the dialyzable fraction of T3. One is the time at which equilibrium is reached, a minimum of 16 $\mathrm{hr}$. This value is the same as that for T4 $(12,17)$. Second is the concentration of Merthiolate introduced to prevent bacterial growth during dialysis. The $1: 10,000$ concentration employed in the procedure to determine DFT4 gave a marked increase in values of DFT3 over those obtained with the same serum without added Merthiolate because, as has been established by electrophoresis, ${ }^{12}$ Merthiolate displaces T3 from TBG to albumin. However, displacement is avoided when the $1: 20,000$ concentration of Merthiolate is employed. Third, dilution of the starting serum brings about a significant decrease of DFT3 similar to that reported for DFT4 $(12,17)$. Last, impurities in the labeled T3 material may seriously affect determination of total T3 and DFT3. Both $\mathrm{T} 3{ }^{125} \mathrm{I}$ and $\mathrm{T} 3$ ${ }^{131}$ I preparations, as delivered, were regularly contaminated with T4. Thus, preliminary purification is essential.

Two reports are available in which normal total T3 iodine concentration was determined by chemical means. Reported values were $0.14 \mu \mathrm{g}$ per 100 $\mathrm{ml}(7)$ and $0.26 \mu \mathrm{g}$ per $100 \mathrm{ml}(8)$, or 0.23 and $0.43 \mu \mathrm{g}$ per $100 \mathrm{ml}$, as T3. Our study gives a value of $0.33 \mu \mathrm{g} \pm 0.07$ per $100 \mathrm{ml}$ of serum, as T3.

A T3: T4 ratio, as T3 and T4, in the euthyroid group was calculated from our data and a value, 0.052 , found. This corresponds well with the figure, 0.046, reported from an estimate of $\mathrm{T} 4$ and $\mathrm{T} 3$ iodines made with radioisotopes (6).

The increase in total T3 seen in hyperthyroidism, and the decrease in hypothyroidism resemble the well-known changes in total $\mathrm{T} 4$ reported for these conditions (8). However, the changes in total T3 appear to be more pronounced.

Previous estimates of DFT3 have been in good agreement $(12,13)$. A DFT3:DFT4 ratio of between 8 and 10 has been calculated. Our study, however, has permitted, as well, determination of the absolute concentration of free T3 (AFT3). A normal ratio, AFT3: AFT4, of approximately

\footnotetext{
12 Nauman, J., and S. C. Werner. Unpublished data.
} 
1:3 has been observed. The ratio became increased in hyperthyroidism and decreased in hypothyroidism. AFT4 was determined by us by methods outlined in the studies just mentioned $(12,13)$.

The good correlation found to exist in normal sera between total T3 concentration and AFT3 supports the concept that the thyroid hormones and the thyroxine-binding proteins of serum in vitro are in a reversible binding equilibrium (10). However, correlation was less significant when hyper- and hypothyroid sera were studied. A similar observation was made when total $\mathrm{T} 4$ and AFT4 were examined in these disorders (12). Whether T3 binding occurs in vivo has been questioned (21).

Recent work has shown that the volume of distribution of $\mathrm{T} 3{ }^{131} \mathrm{I}$ is about three times that of labeled $\mathrm{T} 4$ and the degradation rate five times that of labeled T4 (22). In the light of these observations, an approximate calculation can be made of the degradation rate for $\mathrm{T} 3$, and therefore the $\mathrm{T} 3$ secretion rate (or at least the production rate). Assuming reasonable values for distribution volume of $\mathrm{T} 4$ and fractional turnover rate constant of 10 liters and 0.10 per day, respectively, the corresponding values for $\mathrm{T} 3$ are 30 liters and 0.5 per day. If we use the average serum T3 concentration we found of $3.3 \mu \mathrm{g}$ per liter, the extrathyroidal $\mathrm{T} 3$ pool is approximately $100 \mu \mathrm{g}$ and the quantity degraded per day is 50 $\mu \mathrm{g}$. This is to be compared with values of about $60 \mu \mathrm{g}$ of iodine daily for degradation of $\mathrm{T} 4$ or about $100 \mu \mathrm{g}$ of T4 daily. That the ratio of T4 to $\mathrm{T} 3$ is much higher in the thyroid than $2: 1$ implies preferential secretion of T3. Such preferential secretion from the thyroid might well explain in whole or in part the "iodine leak" from the thyroid indicated by kinetic analysis $(22,23)$.

\section{References}

1. Gross, J., and R. Pitt-Rivers. The identification of $3: 5: 3^{\prime}$-triiodothyronine in human plasma. Lancet 1952, 1, 439.

2. Roche, J., S. Lissitzky, and R. Michel. Sur la présence de triiodothyronine dans la thyroglobuline. C. R. Acad. Sci., Paris 1952, 234, 1228.

3. Benua, R. S., B. M. Dobyns, and A. Ninmer. Triiodothyronine in the serum of patients treated with radioactive iodine. J. clin. Endocr. 1955, 15, 1367.
4. Arons, W. L., and J. D. Hydovitz. The serum pattern of thyroid hormones in euthyroidism and hyperthyroidism. J. clin. Endocr. 1957, 19, 548.

5. Klein, E. Über die Beziehungen zwischen dem thyreoidalen und peripheren Jodstoffwechsel bei Schilddrüsengesunden und Hyperthyreosen. Acta endocr. (Kbh.) 1960, 34, 137.

6. Shimaoka, K., and B. M. Jasani. The application of two-dimensional paper chromatography and lowlevel counting to the study of triiodothyronine in plasma. J. Endocr. 1965, 32, 59.

7. Pind, K. Paper chromatographic determination of thyroid hormone $\left(3: 5: 3^{\prime}\right.$-triiodothyronine) in serum without radioiodine. Acta endocr. (Kbh.) 1957, 26, 263.

8. Nauman, J. The Behaviour of Iodoamino Acids in Serum of Patients with Hyperthyroidism. National Medical Publishing House (P.Z.W.L.) Warsaw, 1965.

9. Barker, S. B. Further studies on the ceric sulphatearsenious acid reaction for the detection of various analogues of thyroxine. Biochem. J. 1964, 90, 214.

10. Robbins, J., and J. E. Rall. Proteins associated with the thyroid hormones. Physiol. Rev. 1960, 40, 415.

11. Ingbar, S. H., and N. Freinkel. Regulation of the peripheral metabolism of the thyroid hormones. Recent Progr. Hormone Res. 1960, 16, 353.

12. Ingbar, S. H., L. E. Braverman, N. A. Dawber, and G. Y. Lee. A new method for measuring the free thyroid hormone in human serum and an analysis of the factors that influence its concentration. J. clin. Invest. 1965, 44, 1679.

13. Nauman, J., and S. C. Werner. Free T4 and T3 with replacement therapy. Program, Annual Meeting of The Endocrine Society, Chicago, June 1966. (Abstract).

14. Scriba, P. C., H. G. Heinze, R. Landgraf, K. W. Frey, and K. Schwarz. Clinical significance of determination of triiodothyronine bound to serum proteins by dextran gel filtration. Klin. Wschr. 1966, 44, 131.

15. Mandl, R. H., and R. J. Block. Methods for the qualitative, semiquantitative and quantitative determination of iodoamino acids and of inorganic iodide in iodoprotein digests and in human serum. Arch. Biochem. 1959, 81, 25.

16. Murphy, B. E. P., and C. J. Pattee. Determination of thyroxine utilizing the property of proteinbinding. J. clin. Endocr. 1964, 24, 187.

17. Sterling, K., and M. A. Brenner. Free thyroxine in human serum: simplified measurement with the aid of magnesium precipitation. J. clin. Invest. 1966, 45, 153.

18. Oppenheimer, J. H., and M. I. Surks. Determination of free thyroxine in human serum: a theoretical and experimental analysis. J. clin. Endocr. 1964, 24, 785. 
19. West, C. D., V. J. Chavre, and M. Wolfe. A serum thyroxine method: application in thyroid disease and iodine-treated patients. J. clin. Endocr. 1965, 25, 1189.

20. Barker, S. B. Determination of protein-bound iodine. J. biol. Chem. 1948, 173, 715.

21. Zaninovich, A. A., H. Farach, C. Ezrin, and R. Volpé. Lack of significant binding of L-triiodothyronine by thyroxine-binding globulin in vivo as demonstrated by acute disappearance of 131 -I labelled triiodothyronine. J. clin. Invest. 1966, 45, 1290.

22. Fisher, D. A., and T. H. Oddie. Whole body counting of 131-I labelled triiodothyronine. J. clin. Endocr. 1964, 24, 733.

23. DeGroot, L. Kinetic analysis of iodine metabolism. J. clin. Endocr. 1966, 26, 149. 